\title{
Dampak Sosial Pariwisata Di Bali Dalam Kartun Bog-bog edisi 2011/2012
}

\author{
I Wayan Swandi \\ Fakultas Pasca Sarjana Universitas Udayana \\ Kajian Budaya \\ E-mail penulis : wayankerobokan@yahoo.com
}

\begin{abstract}
Dampak dari pertumbuhan industri wisata di Bali dapat dilihat dari sisi positif dan negatifnya.Selain pertumbuhan ekonomi dan berbagai kemajuan fisik, Bali menghadapi dilemma kemerosotan dalam aspek sosial dan budaya.Berbagai fenomena sosial di Bali tersebut diungkapkan oleh majalah kartun Bog-Bog dengan nada parodi dan satir. Penelitian ini menggunakan metode kualitatif intepretatif dengan menganalisi gambar-gambar dari majalah kartun Bog-Bog edisi 2011-2012. Hasil analisis pada gambar majalah tersebutmengungkap makna-makna antaralain: 1) Menguatnya Faham Materialisme; 2) Kemacetan dan Kriminalitas; 3) Perubahan Gaya Hidup; 4) Eksklusivitas Tempat Wisata Tetentu; dan5) Citra Bentukan Pariwisata Bali.
\end{abstract}

Kata Kunci: Dampak Sosial, Pariwisata, Kartun Bog-Bog

\section{The Impacts of Tourism Industry Social in Bali in Bog - Bog Cartoon Edition 2011/2012}

The impact of tourism industry growth in Bali can be perceived in to two different sides; positive impact and negative impact. Furthermore, the economic development and infrastructure improvement in Bali ironically brought devaluation of socio and cultural aspects. Bog-Bog Bali Cartoon Magazine reflected the social phenomenon in Bali by incorporating parody and satire tone. This study used interpretative qualitative method, through analyzing pictures of Bog-Bog Bali Cartoon Magazine 2011/2012 edition. The result of the analysis on the pictures shows some meanings, namely: 1) Empowering Materialism, 2) Traffic Jam and Criminality, 3) Life Style Shifting, 4) Exclusivity of Particular Areas, and 5) Images Created of Bali's Tourism.

Keywords: Social Impacts, Tourism, Bog-Bog Bali Cartoon Magazine.

Proses Review : 19 April - 4 Mei 2017, Dinyatakan Lolos : 8 Mei 2017

\section{PENDAHULUAN}

Pertumbuhan pariwisata di Bali menimbulkan dampak sosial yang telah mengubah Bali dalam kurun waktu empat dekade terakhir. Secara positif yang terlihat ada pertumbuhan ekonomi yang mengubah struktur ekonomi Bali yang agraris menjadi industri jasa. Masfeld dan Pizam (2006:261), berpendapat pariwisata di Bali telah menjadi industri dengan sistem yang modern dan infrastruktur yang baik. Lebih jauh Pitana (1999) menjelaskan bahwa pariwisata sudah menjadi breadandbreath bagi separuh lebih penduduk Bali. Jika ditinjau pertumbuhan wisata, misalnya PHR (Pengusaha Hotel dan Restoran) merupakan sumber PAD (Penghasilan Asli Daerah) yang sangat besar perannya. Pada tahun 1999/2000 jumlah PHR yang dihasilkan mencapai Rp 299,483 milyar dan tahun 2001 angka ini naik menjadi Rp 421,853 milyar. Dari sektorketenagakerjaan, tahun 1995 pariwisata menyerap 34, $14 \%$ dari seluruh tenaga kerja di Bali.Tiga tahun kemudian naik menjadi 38\% (Pitana, 1999).

Di balik angka-angka pertumbuhan ekonomi, ternyata ada dampak negatif yang ditimbulkan oleh pariwisata. 
Nilai-nilai tradisional yang dihidupi oleh orang Bali kian hari kian memudar digantikan oleh fahamfaham asing yang masuk melalui pariwisata. Penelitian Burns dan Holden (1995) menyebutkan pariwisata memberikan keuntungan sosial ekonomi pada satu sisi, tetapi di sisi yang lain membawa ketergantungan dan ketimpangan sosial. Dampak sosial kultural kian hari kian dalam, seperti motifmotif ekonomi menjadi prioritas masyarakat yang kemudian berdampak pada eksploitasi seni budaya dan alam Bali. Pada sebuah kesempatanmantan Bupati Gianyar Made Kembar Kare menyebutkan perubahan tersebut sebagai merta matemahan wesia atau berkah yang telah berubah menjadi racun (Bali Post, 2015).

Dampak-dampak sosial kepariwisatan Bali merupakan sumber inspirasi bagi kartunis majalah Bog$B o g$ yang peduli terhadap perubahan tatanan sosial di Bali terutama di era globalisasi. Kartun Bog-Bog menampilkan fenomena sosial dengan nada humor, parodi dan satir. Sejak diterbitkan pertama sekali pada tahun 2001, majalah Bog-Bog terus menerus mengkritisi keadaan Bali dengan mengangkat isu-isu lokal dan sektoral. Dalam hal ini peneliti memberi perhatian pada intepretasi dan pemaknaan dari berbagai gambar-gambar kartun Bog-Bog yang mengangkat masalah-masalah sosial kultural.

\section{METODOLOGI}

Penelitian ini merupakan penelitian kualitatif dengan menggunakan teknik deskriptif intepretatif. Data primer diperoleh dari gambar kartun majalah Bog-Bog edisi tahun 2011/2012. Penelitian ini diadakan di kota Denpasar di mana sumber data primer dan sekunder diperoleh. Data sekunder berasal dari berbagai literatur, laporan ilmiah, dan website yang terkait dengan objek peneltian. Data yang diperoleh dianalisis dengan teori semiotik, teori dekonstruksi dan teori simulakrum.

\section{PEMBAHASAN}

Sebagai media cetak yang menekankan aspek visual, majalah kartun Bog-Bog mengangkat berbagai gejala sosial di Bali melalui gambar-gambar sederhana yang humoris, tetapi mampu mengajak pembaca untuk berfikir dan merenung. Kritik-kritik sosial bahkan mungkin bernuansa politis dikemas dalam format parodi dan satire, sehingga muatan yang berat menjadi terkesan ringan. Majalah Bog-Bog sudah berdiri sejak tahun 2001 dan kiprahnya sudah diakui oleh masyarakat Bali. Secara nasional majalah Bog-Bog berhasil mencatat sebuah keberhasilan sebagai satu-satunya majalah kartun sosial yang eksis. Majalah ini juga telah diterima oleh penikmat kartun internasional, dan menjadi referensi bagi peneliti kartun internasional khususnya melalui riset-siset kartun.

Penelitian ini membahas beberapa makna yang terungkap dari gambar-gambar kartun Bog-Bog edisi tahun 2011/2012 terkait dengan pariwisata di Bali. Beberapa di antaranya adalah: 1)Menguatnya Faham Materialisme; 2) KemacetandanKriminalitas; 3) Perubahan Gaya Hidup; 4) Wilayah-wilayah Publik yang Eksklusif; dan 5) Citra-citra Bentukan Pariwisata Bali.

\section{Menguatnya Faham Materialisme}

Masyarakat Bali kontemporer ditandai dengan menguatnya motif ekonomi (materialisme). Materialisme adalah faham yang masuk melalui globalisasi. Materialisme merupakan pandangan yang bertitik tolak dari pada materi (benda). Studi menunjukkan materialisme merupakan mesin yang menggerakkan ekonomi: "... when citizens are highly focused on goals for making a lot of money, having many possessions, and attaining high status, nations pursue highly competitive forms of capitalism with little governmental regulation”, “...ketika penduduk fokus pada tujuan menghasilkan banyak uang, memiliki banyak harta benda, dan memperoleh status yang lebih tinggi, negara dengan nilai kompetitif yang tinggi akan membentuk sistem kapitalisme dengan sedikit regulasi dari pemerintah" (Kasser, Cohn, Kanner, \& Ryan, 2007; Schwartz, 2007). Namun demikian dalam konteks masyarakat yang kian materialis, nilai-nilai kejujuran menjadi barang yang langkah.

Booming ekonomi pariwisata mengubah masyarakat yang komunal dan immaterial menjadi lebih individualis dan materialis. Salah satunya dapat dibuktikan dalam bidang seni. Dengan mengamati lebih seksama, saat ini kegiatan berkesenian tidak lagi seni untuk mengolah rasa tetapi bertujuan mendulang emas dan dolar. Pada masa lalu, kegiatan menari dilakukan secara mengayah atau sukarela sebagai bakti pada Tuhan Yang Maha Esa pada acara-acara keagaamaan atau 
pada acara pancayadnya lainnya. Kini setiap dedikasi bernilai dan dihargai dengan sejumlah uang. Penari, tukang tabuh, maupun seniman lainnya menuntut bahkan mematok harga sebagai imbalan atas jerih payah mereka dengan sejumlah uang (lihat Gambar1).

Pariwisata Bali secara khusus menjual pusaka budaya (cultural heritage), menurut Richard (dalam Ardika 2007:47) pusaka budaya mampu digunakan sebagai modal pengembangan pariwisata. Wisatawan mengkonsumsi objek-objek berestetika, bersejarah dan mengandung nilai-nilai emosi tertentu. Hubungan relasi ekonomi dan budaya dalam konteks pariwisata berdampak buruk dan merusak terhadap pusaka budaya (Burns dan Holden, 1995). Komodifikasi budaya yang diungkapkan Burns dan Holden secara real kini terjadi dari mulai seni budaya Bali sampai upacara keagamaan seperti odalan, ngaben, melasti dan sebagainya.

Pariwisata Budaya memiliki konsekuensi komersialisasi budaya (Geriya, 1983). Oleh beberapa pengamat budaya, Bali dikhiaskan sebagai pasar seni budaya, tempat orang-orang berjual beli seni budaya. Menurut Ardika (2003) semua aspek seni budaya telah mengalami komersialisasi termasuk seni tari. Seni tari menjadi suguhan hiburan bagi tamu asing pertama dalam sejarah pariwisata Bali terjadi tahun 1930 an (Vickers, 1996:121). Tari yang pertama kali disuguhkan kepada turis pada waktu itu adalah tari kecak, yang dibawakan oleh sanggar yang dikoordinasi oleh Walter Spies.

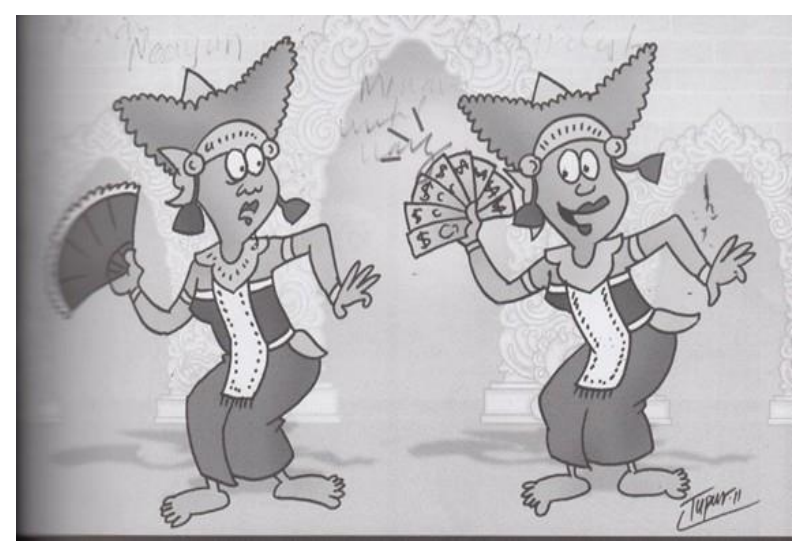

Gambar 1. Penari Kipas Uang (Tema Kipas). Sumber: Bog-Bog Cartoon Magazine No.5. Vol. 10 Tahun 2011
Walaupun ekspoitasi yang bersifat bisnis terjadi dalam ranah seni budaya, fakta lain menunjukkan adanya dampak konservasi budaya. Dalam perspektif budayawan strukturalis, komersialisasi budaya identik dengan pedangkalan makna, profanisasi dan banalisasi budaya tinggi (Ardika, 2003). Pemikiran seperti itu mendapatkan perlawanan dari kelompok dekonstruktivisme. Komersialisasi dibaca berbeda oleh kaum dekonstrutivisme sebagai upaya konservasi. Nilai-nilai ekonomi sebagai konsekuensi komersialisasi mampu mendorong masyarakat untuk memelihara seni budaya. Subadra (2006) berpendapat, pengembangan pariwisata terkait dengan pelestarian budaya masyarakat lokal, seperti; kegiatan keagamaan, adat-istiadat dan tradisi, serta diterimanya pengembangan objek wisata dan kedatangan wisatawan oleh masyarakat lokal. Kegiatan pariwisata Bali menurut R.M. Soedarsono (1999) telah menimbulkan kreativitas-kreativitas baru dengan munculnya jenis kesenian yang secara khusus disajikan untuk tontonan wisata. Perkembangan khasanah seni pertunjukkan dalam konteks pariwisata menciptakan sebuah nomenklatur baru dalam kepariwisataan di Bali yang disebut dengan tourist art atau art of acculturation (Ardika, 2005: 84-85)

Menguatnya materialisme dalam masyarakat menyebabkan komodifikasi budaya tak terhindarkan. Pemerintah dan masyarakat menyadari kecenderungan komersialisasi budaya untuk kepentingan pariwisata (Putra, 2006). Pariwisata membutuhkan banyak tontonan dan atraksi, masyarakat merespon dengan menyediakan permintaan akan hiburan. Menurut Benjamin (dalam Piliang, 2003: 98) seni dapat direproduksi dalam jumlah banyak dan dinikmati oleh semua orang. Prinsip ini menantang status otonomi seni: "bahwa seni adalah milik khalayak luas, massa". Materialisme bukan ajaran Hindu Bali yang cenderung menjauhi materi, tetapi materialisme menyebabkan kegairahan baru, dorongan untuk maju dan sangat dibutuhkan dalam pembangunan.Cara pandang baru menyebabkan pergeseran nilai dalam masyarakat Bali. Sebuah cara pandang yang dekonstruktif yakni menolak struktur lama yang telah lazim dan mapan membuka ruang-ruang sepeti materialisme untuk tumbuh dalam ruang-ruang sosial budaya. 
Pertumbuhan ekonomi pariwisata yang menjanjikan banyak dollar merubah prilaku masyarakat. Pada Gambar 2 digambarkan seorang turis mancanegara sedang menawar seekor burung yang mampu berkicau dengan merdu. Sang penjual burung kemudian mematok harga dua kali lipat mahalnya. Padahal pada sangkar hanya terlihat sebuah radio yang memainkan suara burung.

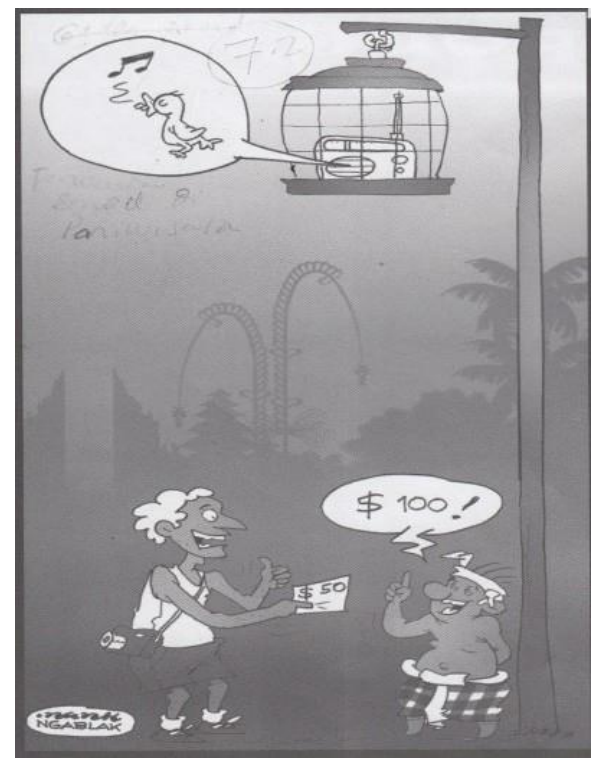

Gambar 2. Pedagang Burung (Tema Radio). Sumber: Bog-Bog Cartoon Magazine No.2. Vol 10 Tahun 2011

Penelitian Doxey tahun 1975 (dalam Pitana:2005), sejalan dengan tingkat perkembangan pariwisata atau jumlah wisatawan, terjadi akumulasi sikap negatif masyarakat lokal terhadap wisatawan.

\section{Kemacetandan Kriminalitas}

Persolan kepariwisataan Bali lain yang diangkat oleh majalah Bog-Bog adalah kemacetan. Masalah kemacetan di Bali khususnya di wilayah Bali Selatan bahkan sempat menjadi sorotan dunia Internasional. Seorang wartawan majalah Times, Andrew Marshall pada medio April, 2011 mempublikasikan tulisannya yang berjudul "Holidays in Hell: Bali's Ongoing Woes". Dalam tulisannya Marshall mengeluhkan keadaan Bali yang semakin tidak nyaman diantaranya masalah lalulintas yang macet.

"Itchy ocean? Just add it to Bali's growing list of seemingly intractable problems: water shortages, rolling blackouts, uncollected trash, overflowing sewage-treatment plants and traffic so bad that parts of the island resemble Indonesia's gridlocked capital Jakarta." (Time, 2011).
"Air laut yang gatal? Ini hanya menambahkan ke daftar bahwa Bali sedang bermasalah yang tampaknya semakin rumit seperti kekurangan air, pemadaman listrik bergilir, sampah yang menumpuk, luapan ganggang, pengolahan air limbah dan lalu lintas yang begitu buruk belum lagi Bali menjadi pulau menyerupai ibukota, macet seperti Jakarta." (Time, 2011)

Gambar 3 menggambarkan seorang laki-laki Bali dengan pakaian ritual dan membawa payung (tedung), sarana yang biasa digunakan pada sebuah arak-arakan ritual seperti melasti. Perjalanannya terhenti di tengah jalan yang situasinya persis berada di tengah lautan kenderaan beroda empat yang ikut terjebak kemacetan. Kemacetan di Bali terjadi seiring dengan meningkatnya aktivitas bisnis terutama terkait pariwisata.

Potensi ekonomi pariwisata membuka banyak peluang dan manfaat bagi masyarakat di dalam lokasi wisata maupun wilayah lain disekitarnya. Kedatangan wisatawan asing mengundang kaum muda untuk datang memanfaatkan peluang kerja. Akibatnya terjadi perpindahan penduduk dari wilayahwilayah disekitar wilayah pariwisata. Akumulasi perpindahan penduduk menyebabkan wilayah wisata menjadi overcrowding yang berdampak pada masalah-masalah sosial baru seperti kemacetan.

Dari perpekstif budaya, kemacetan di Bali merupakan penanda perubahan sosial masyarakat yang dulunya sebagai masyarakat rural (pedesaan) bertransformasi menjadi masyarakat urban (perkotaan). Daerah-daerah seperti Kuta, Seminyak, dan Legian tadinya adalah wilyah desa dan persawahan yang sepi, dalam tiga dekade berubah menjadi daerah yang padat, sibuk dan macet.

Sejatinya kemancetan lalulintas membuat susah masyarakat, namun ada pendapat yang berbeda mengenai hal ini. Menurut kartunis Bog-Bog, orang Bali bersikap permisif terhadap kemacetan karena beberapa alasan antara lain: 1) kemacetan sering bersumber dari kegiatan upacara. Setiap kali ada kegiatan upacara, biasanya ada bagian jalan yang ditutup; 2) adanya anggapan kemacetan merupakan sumber rezeki, dan sebagai indikator perekonomian yang membaik. Bali yang padat dengan pengunjung bermakna penambahan pemasukan sekaligus kemacetan. 
Dua kondisi dalam satu paket yang harus diterima oleh masyarakat yang hidup dari sektor pariwisata.

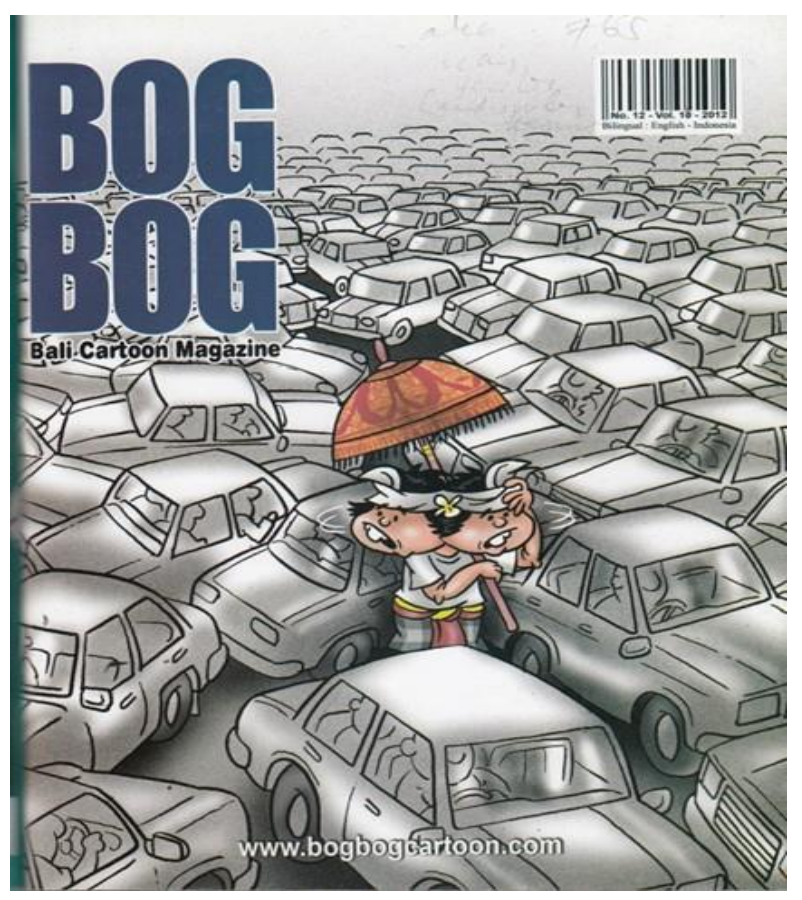

Gambar 3. Cover Bog Bog Cartoon Magazine No.10. Vol 10 2012.. Sumber: Bog Bog Cartoon Magazine No.10. Vol. 10 Tahun 2012.

Pasca bom Bali, kewaspadaan atau kesadaran akan pentingnya menjaga keamanan dan ketertiban masyarakat semakin tinggi. Pariwisata juga merupakan pintu masuk penyebaran kejahatan dan narkoba yang beroperasi secara transnasional. Sejak dibangunnya lapangan terbang Internasional Ngurah Rai tahun 1969 tamu-tamu asing dari mancanegara berdatangan langsung tanpa melalui Jakarta. Pada gambar 4 digambarkan situasi pemerikasaan (chekpoint) di bandara. Seorang petugas sedang memeriksa sebuah barong. Di dalam barong tersebut bersembunyi dua orang pelaku kriminal dengan kostum khas penjara dengan motif bergaris-garis hitam.

Kepariwisataan Bali memiliki daya tarik bagi pendatang dengan berbagai motivasi. Penelitian Pizam et all tahun 1982 (dalam Pitana: 2005) menyimpulkan bahwa pariwisata berpotensi sebagai faktor penentu munculnya berbagai bentuk kriminal. Dalam sepuluh tahun terakhir menurut BPS dalam terjadi peningkatan jumlah penduduk berkisar empat persen pertahun, khususnya di Denpasar.
Penelitian Amminulah; peningkatan jumlah penduduk di Bali berkorelasi pada peningkatan angka kriminalitas.

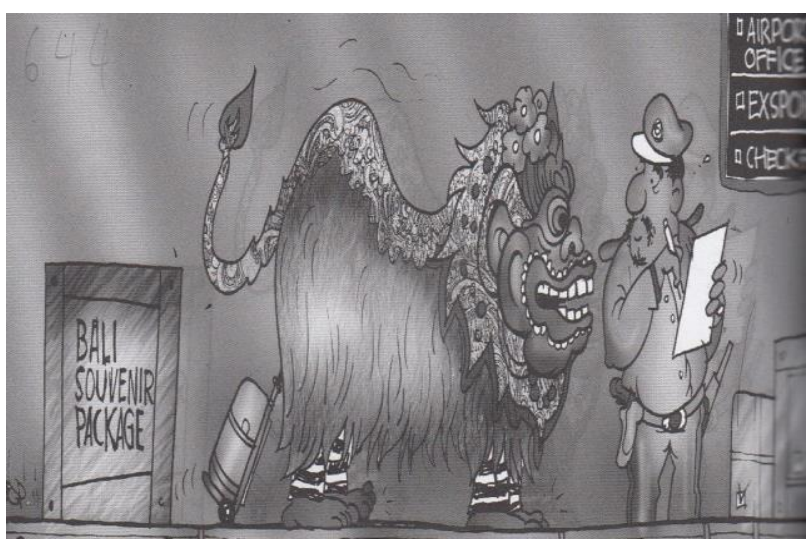

Gambar 4. Cop-fee Susu (Tema Globalisasi). Sumber: Bog Bog Cartoon Magazine No.6. Vol. 10 Tahun 2011.

Fenomena materialisme dalam masyarakat Bali kontemporer menunjukkan pergeseran nilai-nilai tradisional yang mengakar pada filsafat Hindu yang immaterial menjadi nilai-nilai baru yang berbasis ekonomi (materialisme). Dalam penjelasan Marxisme, kesadaran manusia adalah kesadaran kelas dalam banyak lapangan kehidupan. Oleh Harris (dalam Saifuddin, 2006:237) disebutkan bahwa prilaku manusia dikontrol oleh persyaratan kebutuhan protein, energi, atau faktor-faktor alamiah lainnya. Apa yang dikemukakan Harris hanya menjadi ilustrasi untuk menjelaskan motif-motif tindak kriminal yang terjadi akhir-akhir ini di Bali, terutama setelah sektor pariwisata berkembang pesat. Umumnya para prilaku kriminalitas mengakui motivasi tindakannya untuk memenuhi kebutuhan dasar.

Pertumbuhan ekonomi tidak serta merta mengangkat seluruh lapisan masyarakat. Masyarakat yang tertinggal menunjukkan adanya gap pembangunan yang tidak merata. Pariwisata menurut Mathielson dan Wall (dalam Pitana, 2005) telah mengubah struktur internal masyarakat, sehingga terjadi pembedaan antara masyarakat yang terkait dengan pariwisata dengan yang tidak. Penelitian Burns dan Holden (1995) dan McIntosh (1995) pariwisata menciptakan ketimpangan sosial, kecemburuan sosial dan ketidaksenangan akibat gap ekonomi dalam masyarakat. Semua ini bermuara kepada peningkatan tindak kriminalitas. 


\section{Perubahan Gaya Hidup}

Mengamati perkembangan pariwisata di Bali, terlihat jelas bahwa trend pariwisata di Bali bergerak mengikuti trend wisata dunia. Wilayah Selatan Bali adalah sebuah kasus di mana pariwisata berkembang mengikuti selera pasar yakni selera turis barat. Tumbuhnya pusat-pusat hiburan seperti night club, cafe, dan sejenisnya membuktikan dunia malam atau night life sudah menggejala di Bali Selatan. Sebuah keadaan yang sangat berbeda dengan kondisi tiga puluh tahun lalu.

Pada Gambar 5, digambarkan dua orang pria Bali sedang menikmati kegiatan malam mereka yang tenang dan damai dengan mengobrol, membaca lontar ditemani oleh kopi Bali. Seiring dengan berjalannya waktu, mereka tidak sendiri lagi.Ada orang-orang lain disekitar mereka. Sampai suatu saat orang-orang disekitar mereka sudah membentuk kerumunan. Kini mereka berada ditengah hiruk pikuk kegiatan malam orang-orang asing.

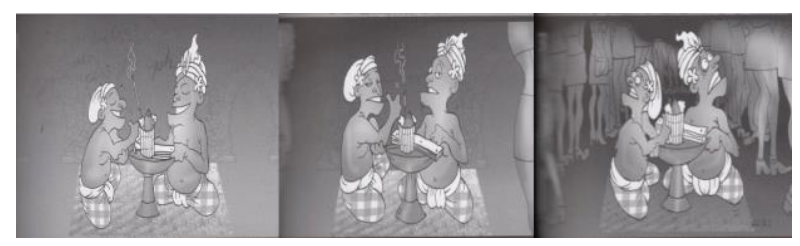

Gambar 5. Night Live Past Present Future.

Sumber: Bog Bog Cartoon Magazine No.5. Vol. 10 Tahun 2011

Penggambaran situasi pada kartun di atas mendekati realitas sebenarnya. Dahulu masyarakat Bali yang bersahaja tidak memiliki banyak aktivitas di malam hari. Kaum wanita tinggal dirumah, para pria berkumpul menghabiskan waktu sekedar mengobrol atau membahas lontar. Sekarang suasana seperti itu sulit ditemukan. Malam tidak sepi dan tenang lagi berubah menjadi gemerlap cahaya lampu-lampu diskotik dan suara hingar bingar musik sebagai penanda kehidupan malam di Bali.

Kehidupan malam di Bali memiliki implikasi sosial. Sebuah tulisan yang dimuat di Bali.com menuliskan bagaimana kehidupan malam di Bali Selatan.

"In Bali's discos, clubs, bars and even pubs you'll meet also many young local girls, "kupu kupu malam" ("night butterflies") or working girls mostly coming from the poorer rural areas of Java) and young boys who compete with the females.
All taxi drivers, security guards, street vendors will know the more "popular" karaoke bars and massage parlours in Kuta, Legian and Denpasar, along with the various "Houses of ill Repute" in narrow back lanes. These helpful people want to share their knowledge, whether you want to know or not. Anything you might be tempted to experience or consume is available. A silent but direct "massage?, young girls?, marihuana?" slips the tongue of many you might pass, while walking the streets of Kuta, Legian or Seminyak."

"Di Bali, tempat-tempat seperti diskotik, klub, bar dan bahkan pub, anda akan bertemu juga banyak gadis muda lokal, "kupu kupu malam" atau gadisgadis yang bekerja malam hari sebagian besar berasal dari daerah pedesaan miskin (di Jawa) dan anak laki-laki muda yang bersaing dengan kaum perempuan. Semua supir taksi, penjaga keamanan, PKL akan mengetahui karaoke yang paling populer, bar dan panti pijat di Kuta, Legian dan Denpasar, bersama dengan berbagai tempatpelacuran di gang-gang sempit. Mereka akan membantu berbagi informasi, apakah anda ingin tahu atau tidak. Apa pun yang mungkin membuat anda tergoda untuk alamai dan konsumsi ada tersedia. Untuk pijat?tapi Gadis-gadis muda ? ganja ?kalau salah bicara anda akan melewatinya, sambil berjalan -jalan di Kuta, Legian atau Seminyak. "(Bali.Com, 2016)

Gaya hidup malam yang merebak di daerah Bali Selatan menurut (Natzir, 2008) adalah akibat bergesernya struktur masyarakat rural menjadi masyarakat urban dengan etos baru yang menganggap siang adalah hari atau waktunya untuk bekerja sedangkan malam hari saatnya melakukan interaksi sosial. Sedangkan Hunt dan Moloney (2010) menganggap kelompok anak muda yang bepergian keluar pada malam hari bertujuan untuk menikmati suatu sarana hiburan sebagai sebuah gaya hidup.

Perubahan gaya hidup seperti nite life di Bali menjelaskan sebuah fenomena homogenisasi budaya. Gaya hidup malam (nite life) adalah budaya Barat. Menurut Pitana dan Gayatri (2005: 116), yang terjadi dalam homogenisasi budaya adalah identitas etnik lokal tenggelam dalam bayangan sistem industri dengan teknologi barat, birokrasi nasionaldan multinasional, a consumer-oriented economy, dan jet-age lifestyles. Jelas bahwa gaya hidup yang ditunjukkan oleh masyarakat Bali kontemporer 
bukan berasal dari budaya asli tradisional Bali. Melainkan karena pengaruh budaya asing yang lebih menonjolkan permukaan dari pada isi. Menurut Pilliang (2006) era kontemporer (postmodern) merupakan sebuah era pemujaan permukaan atau kulit luar yang mengejar ekstasi pemuasan (pleasure) nafsu-nafsu badaniah.

\section{Wilayah-wilayah Publik Yang Ekslusif}

Pariwisata di Bali makin maju karena mampu mendatangkan investor dari penjuru dunia.Menurut Badan Pusat Statistik provinsi Bali tahun 2013 jumlah hotel berbintang lima ada 54 hotel, berbintang empat ada 62 hotel, hotel berbintang tiga ada ada 63 buah. Hotel-hotel tersebut umumnya milik investor asing dengan pendanaan yang kuat sehingga mampu menguasai lahan-lahan yang luas. Dengan harga jual tanah di Bali yang terus naik, berkisar 400 persen setiap tahun, masyarakat tergiur melepas milik mereka kepada investor. Hasil penelitian K3NI (Kelompok Kerja Krisis Nominee Indonesia) ada 50.000 warga negara asing (WNA) memiliki properti dan tanah di Bali. Ada 7500 kepemilikan villa oleh orang asing (Berita Bali. 2015).

Majalah Bog-Bog melihat kecenderungan berkurangnya hak-hak publik mengakses terhadap kawasan tertentu yang dahulu bebas dimasuki. Gambar 6 merupakan sebuah satire ironi pariwisata di Bali. Pada gambar ada terlihat seorang pria Bali sedang menatap sebuah lukisan Tanah Lot yang digambarkan dengan cerobong asap menyerupai kapal laut. Lukisan ini dibingkai dan ditutupi tirai bermotif dollar (\$).

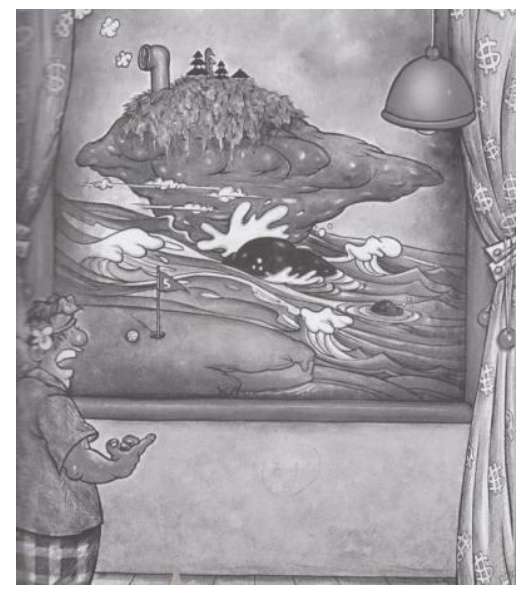

Gambar 6. Lukisan Tanah Lot.

Sumber: Bog Bog Cartoon Magazine No.2. Vol. 10 Tahun 2011
Melalui pendekatan simulacrum, gambar tersebut merupakan duplikasi/tiruan atau daur ulang dari objek asli yang berfungsi sebagai simulasi.Jadi bukan representasi dari sebuah realitas sesungguhnya. Gambar tersebut seolah-olah mencoba memprediksi masa depan Bali. Ada sebuah kecenderungan ketika pariwisata semakin signifikan peranannya dalam kehidupan masyarakat, secara linear terjadi peningkatan status ekslusif wilayah-wilayah tertentu. Masyarakat tidak lagi secara bebas memasuki areal tertentu yang tadinya milik publik. Gambar di atas misalnya, bercerita tentang Tanah Lot yang terjual dan mungkin hanya dapat dinikmati dari sebuah lukisan. Artinya orang Bali kelak hanya dapat menikmati gambar-gambar simulakrum tentang keindahan tanah leluhur mereka yang sudah dimiliki oleh orang asing. Tirai-tirai dolar sebuah khiasan untuk menggambarkan hak eksklusif bagi orang-orang kaya.

Dalam realitas kekinian, dampak penguasaan lahan oleh asing, beberapa kawasan di Bali kini mulai terlarang untuk publik karena pemilik hotel atau villa meminta hak eklusif pemandangan di sekitarnya. Beberapa dari investor mengikat kontrak dengan masyarakat lokal. Salah satu contoh misalnya apa yang terjadi di Tanah Lot di mana subak-subak di sekitar pura Tanah Lot dikuasai oleh grup Bali Nirwana Resort (BNR). Perselisihan hukum atas kepemilikan tanah dan hak penggunaan ruang publik sudah terdengar di sana-sini.

Gambar 6 disamping juga membicarakan tentang komoditisasi pemandangan. Bentang alam atau panorama Bali yang tidak lagi dinikmati atau diakses secara gratis. Ada banyak wilayah pantai, subak, wilayah suci dan lainnya dikenakan tarif masuk, di mana pada masa lalu fenomena seperti ini tidak terjadi. Dahulu pernah terjadi di Desa Jatiluwih,bila wisatawan asing membidikan kamera pada seseorang atau suatu objek seperti alam maka orang lokal yang melihat akan menengadahkann tangannya dan mengatakan "One dollar sir!" Kini masyarakat juga memanfaatkan biaya shotting baik dalam bentuk produksi gambar maupun filem yang dilakukan wisatawan. Di daerah-daerah berkembangnya agroturisme seperti wilayah subak, penduduk lokal mengenakan biaya pemandanga (view cost) bagi hotel, villa serta penginapan lainnya yang berada disekitar lokasi subak. Salah satu ciri dari masyarakat yang materialistik adalah 
menggejalanya komoditisasi aspek-aspek hidup yang non komersial. Menurut Turner (dalam Prasiasa, 2011) hal ini terjadi karena masyarakat yang hidup dalam pengaruh kuat kapitalisme memiliki semangat menciptakan keuntungan sebesarbesarnya.

\section{Citra-citra Bentukan Pariwisata Bali}

Pada era awal kepariwisataan di Bali di mana wisatawan Eropa datang mengunjungi Bali karena keunikan Budayanya. Tak sedikit dari mereka berasal dari kalangan akedemis, peneliti budaya khususnya dari disiplin ilmu antropology yang datang dan pulang membawa oleh-oleh berupa karya tulis ilmiah. Para peneliti tersebut menghasilkan buku-buku berkualitas yang dibaca oleh masyarakat dunia.Antara lain misalnya, Margaret Mead dengan bukunya "Balinese Character";Clifford Geertz dengan buku Negara: The Theatre State in 19th Century Bali, Dr Gregor Krause, dengan bukunya Bali 1912; Miguel Covarrubias dengan bukunya the Island of Bali;Collin Mc Phee dengan A House in Bali; Mrs Menc (Ni Ketut Tantri) dengan bukunya Revolt In Paradise; Roelof Goris dengan bukunya Prasasti Bali; Lovis Conperus dengan bukunya Easwords; dan Walter Spies dengan Drama in Bali.

Laporan-laporan ilmiah tentang Bali di mancanegara membentuk citra tentang pesona pulau Bali dan kekayaan budayanya sebagai sebuah tamansurga (paradise), tamannya para dewa (pulau dewata). Citra tersebut melekat hingga kini. Namun demikian, perkembangan terkini terjadiperluasan makna-makna baru yang sekaligus menciptakan citra-citra baru bagi pariwisata Bali. Salah satu yang menonjol adalah bagaimana gaya hidup yang berkembang dalam ruang lingkup pariwisata menentukan citra baru bagi pariwisata Bali.

Tipologi pariwisata Bali telah dirancang sebagai pariwisata budaya yang mengacu kepada undangundang. Misalnya, Undang-Undang Nomor 10 Tahun 2009 pasal 13 ayat 3 tentang hak menentukan kawasan khusus wisata dan Perda No 2 Tahun 2012 tentang penentuan Bali sebagai Pariwisata Budaya. Namun demikian, secara alamiah sesuai dengan permintaaan pasar pariwisata, beberapa daerah di Bali Selatan berkembang pariwisata nonbudaya (sekuler). Akhirnya, wisatawan mengenali dua tipologi pariwisata di Bali. Bagi yang ingin menikmati hiburan modern, panorama pantai dan aktivitas berselancar, berjemur dan seterusnya akan pergi ke wilayah Bali Selatan. Bagi wisatawan yang tertarik dengan budaya Bali, benda-benda artistik dan suasana meditatif akan memilih Ubud dan sekitarnya.

Gambar 7 menggambarkan seorang turis mancanegara yang sedang kebingungan membaca petunjuk arah di jalan. Pada papan petunjuk jalan terdapat dua arah, salah satu arah menuju Hospital (Rumah Sakit), merujuk daerah Kuta dan Seminyak. Arah yang lain menuju Heaven (Surga), merujuk daerah Gianyar dan Ubud.

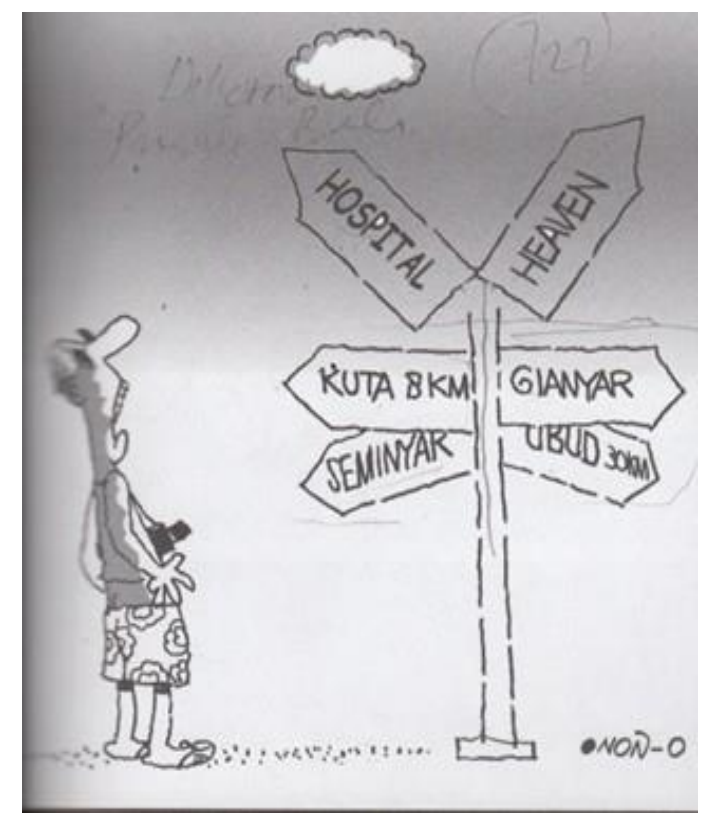

Gambar 7. Dikotomi Pariwisata Bali (Topik Rumah Sakit). Turis mempersepsi wilayah Bali Selatan sebagai pusat turistik sekuler dan Bali Timur sebagai wilayah turistik spiritual. Sumber: Bog-Bog Bali Cartoon Magazine No.6. Vol. 10, 2011

Konstruksi dikotomi pariwisata Bali di wilayah Bali Timur dan Selatan tidak semata-mata terjadi karena permintaan pasar, tetapi karena karateristik sosial budaya masyarakat. Bali Timur dikenal sebagai wilayah dengan pemusatan kegiatan masyarakat dalam pertanian dan berkesenian, sedangkan masyarakat Bali Selatan umumnya beraktivitas sebagai nelayan dan usaha yang terkait dengan wilayah pantai. Justine Vaisutis(2007) mengatakan: "Ubud is the other half of Balis tourism duopoly. Unlikel South Bali, however, Ubud's focus remains on the remarkable Balinese culture in its myriad forms". 
Dikotomi pariwisata di Bali menyebabkan daerahdaerah, seperti Kuta dan Seminyak digambarkan sebagai kawasan turistik global bukan kawasan wisata kultural. Kuta dan Seminyak adalah tempat yang menawarkan hiburan duniawi, atau dalam istilah Baudrillard (dalam Pilliang, 2004) berparade dengan ekstasi hasrat yang memacu hormonal dan mengejar kesenangan (pleasure) semata. Sebaliknya, Ubud dikonstruksi sebagai pusat spiritual di Bali karena masih memegang kuat nilai-nilai budaya dan spiritual Hindu Bali (Indrio, 2009:134).

Majalah kartun Bog-Bog juga menyoroti penjualan bir di Bali. Konsumsi bir di Bali adalah yang terbesar di Indonesia. Menurut data penjualan PT Multi Bintang Indonesia Tbk (MBI), total penjualan bir bintang tahun 2011 Rp 1,7 triliun. Penerimaan cukai negara dari bir pertahunnya 880 milyar. Lima wilayah di Indonesia dengan penjualan Bir Bintang tertinggi adalah Bali, Surabaya, Medan, Jakarta, dan Makassar.

Pada gambar 8 digambarkan seorang "Big Bos" bertubuh gemuk dengan perut yang buncit berpidato dalam rangka ulang tahun "Beer Office". Di belakang podium terlihat jejeran botol-botol bir bintang.

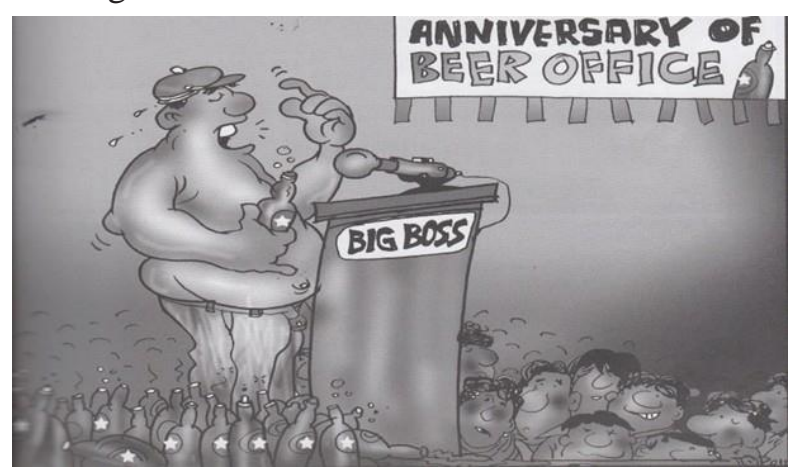

Gambar 8. Beer Office (Tema Waktu). Bali menjadi satu satunya provinsi tanpa larangan penjualan bir secara bebas. Oleh karena itu, citra bir juga melekat dengan wisata Bali. Sumber: Bog-Bog Bali Cartoon Magazine No.6. Vol 10 Tahun 2011Sumber: Bog-Bog Bali Cartoon Magazine No.6. Vol. 10, 2011

Kepopuleran Bali dan Bir Bintang merupakan citra yang muncul di antara citra-citra yang lain sepanjang perkembangan pariwisata yang ekspansif. Selain cendramata khas tradisonal Bali, kaus-kaus singlet dan celana pendek pantai dengan lambang bir bintang menjadi trademark pariwisata di Bali khususnya di daerah Selatan.
Souvenir seperti kaus tanktop Bir Bintang sering digunakan oleh pria-pria asing yang berseliuran sepanjang jalan di wilayah Kuta, Legian dan Seminyak. Citra Bali dan Bir Bintang seolah-olah sudah melekat. Di wilayah lainnya seperti di Jakarta memakai kaus Bir Bintang tidaklah lazim dan terkesan salah tempat. Tetapi bila ada seseorang memakai kaus tersebut,maka yang lainberanggapanbahwa sipemakai baru saja pulang dari liburan ke Bali atau sedikitnya pernah pergi ke Bali.

Di tengah pembatasan dan pengawasan yang ketat oleh pemerintah terhadap minuman beralkohol, aktivitas minum bir menjadi pemandangan yang biasa karena kemudahan mendapatkannya. Dari perspektif budaya, masyarakat Bali sangat cair dalam menerima budaya dari luar, sehingga budaya minum bir, seperti: dietrinkkultur (minum bir), minum wine atau champagne dapat dengan mudah masuk dan diterima oleh masyarakat. Bila ditelusuri dari kehidupan tradisional Bali, pria-pria Bali juga menyukai minuman-minuman keras seperti arak atau tuak.

Kelenturan sikap masyarakat Bali menerima budaya asing seperti mengkonsumsi minuman beralkohol dapat ditelusuri dari faktor internal dan eksternal. Secara internal budaya Bali menurut Griya (2000),mampu mengadaptasi dengan budaya yang masuk. Faktor eksternalnya menurut Pitana dan Gayatri (2005:147), pariwisata memaksa masyarakat dan budaya lokal 'go international' dan mau tidak mau harus menjadi 'warga dunia yang multibudaya' dan menjadi 'tourist society'.

\section{SIMPULAN}

Intepretasi majalah Bog-Bog dari edisi 2011/2012 terhadap dampak sosial kepariwisatan di Bali merujuk kepada beberapa isu antaralain: 1) Menguatnya Faham Materiallisme. Masyarakat Bali menjadi kian materialistik, ditandai dengan fenomena komodifikasi budaya dan memudarnya nilai-nilai kejujuran; 2) Kemacetan dan Kriminalitas. Lalulintas di wilayah-wilayah turistik Bali menjadi kian macet dengan arus lalulintas yang padat. Angka kriminalitas meningkat seiring dengan masuknya pendatang dan tamu wisatawan;3) Perubahan Gaya Hidup. Masyarakat Bali kontemporer mulai meninggalkan cara hidup tradisional yang bersahaja; 
4) Wilayah-wilayah Publik yang Eksklusif. Beberapa tempat publik seperti sawah, pantai, dan kawasan suci di Bali kini dimiliki secara eksklusif oleh pihak swasta; dan 5) Citra-citra Bentukan Pariwisata Bali. Gaya hidup yang berkembang ditengah perkembangan pariwisata menciptakan citra-citra baru bagi pariwisata Bali seperti dikotomi pariwisata Ubud dan Bali Selatan dan Bali the island of Beer Bintang.

\section{DAFTAR RUJUKAN}

Ardika, I Wayan, 2003, Pariwisata Bali: Membangun Pariwisata Budaya dan Mengendalikan Budaya Pariwisata. Denpasar: Kajian Pariwisata Program Pascasarjana Universitas Udayana.

Pariwisata, Denpasar: Pustaka Larasan.

Burns, Peter, M. and A. Holden. 1995. Tourism a New Perspective. London: Prentice Hill.

Geriya, I Wayan. 1993. "Pariwisata dan Segi Sosial Budaya Masyarakat Bali" dalam Kebudayaan dan Kepribadian Bangsa (Tjok Sudharta, dkk. Ed.). Denpasar: Upada Sastra.

Hunt, Geofrey, Molly Moloney dan Kristin Evans. 2010. Youth, Drugs, and Nightlife. London: Routledge

Kasser T, Cohn S, Kanner A.D, \& Ryan R.M. 2007. "Some Costs of American Corporate Capitalism: A psychological Exploration of Value and Goal Conflicts" dalam Psychological Inquiry, 18, 1-22.

Masfeld, Yoel dan Abraham Pizam. 2006. Tourism, Security and Safety: From Theory to Practice. London: Routledge.

Nazsir, R Nasrullah. 2008. Teori dan Sejarah Pertumbuhan Masyarakat Kota: Kajian Kritis Aspek-Aspek Transformasi Masyarakat RuralUrban. Bandung: Widya Padjadjaran.

Pilliang, Yasraf Amir. 2005. Transpolitika Dinamika Politik di dalam Era Virtualitas. Yogyakarta: Jalasutra.
Pitana, I Gde (ed). 1994. Dinamika Masyarakat dan Kebudayaan Bali. Denpasar: Penerbit Bali Post.

Pitana, I Gde dan Putu G. Gayatri. 2005. Sosisologi Pariwisata. Yogyakarta: Penerbit ANDI.

Prasiasa, Dewa Putu Oka. 2011. Wacana Kontemporer Pariwisata. Jakarta: Salemba Humanika

Putra, Darma I Nyoman. 2006. "Pariwisata Budaya, antara Polusi dan Solusi: Pengalaman Bali" dalam Masalah Budaya dan Pariwisata dalam Pembangunan. Denpasar: Program Studi Magister (S2) Kajian Budaya Universitas Udayana.

Saifuddin, Achmad Fedyani. 2006. Antropologi Kontemporer: Jakarta: Kencana Prenada Media Group.

Soedarsono, R.M. 1999. Seni Pertunjukkan Indonesia dan Pariwisata. Bandung: MasyrakatSeni Pertunjukan Indonesia.

Vaisutis, Justineet all. 2007. Lonely Planet: Indonesia. Jakarta: Gramedia.

Vickers, Adrian. 1996. Bali: A Paradise. Victoria: Ringwood. 


\section{Sumber Websites}

AntaraNews. 2015. Polri Ringkus Warga Bulgaria Pelaku Pembobol ATM, sumber:

http://www.antaranews.com/berita/491935/polriringkus-warga-bulgaria-pelaku-pembobol-atm Diakses 18 Maret 2016

Bali.Com. 2016. Night Life, Party Bars, \& Clubbing. Sumber:https://www.bali.com/nightlife.html diakses 4 April 2016.

Berita Bali, 2015. 50 Ribu Warga Asing Miliki Properti di Bali Senilai Rp 109 Triliun. Sumber: http://beritabali.com/read/2015/03/25/2015032500 05/50-Ribu

Warga-Asing-Miliki-Properti-di-Bali-Senilai-Rp109-Triliun.html diakse 6 April 2016.
PopBali. 2013. 10 Perubahan Paling Drastis Dalam Masyarakat Bali Per 2013. Sumber: http://popbali.com/10-perubahan-paling-drastisdalam-masyarakat-bali-per-2013/ Diakses 5 April 2016.

, 2013.Kejahatan oleh Orang Asing di Bali Terjadi Setiap Minggu, sumber:

http://popbali.com/kejahatan-oleh-orang-asing-dibali-terjadi-setiap-minggu/ Diakses 18 Maret 2016

Time, 2011.Holidays in Hell: Bali's Ongoing Woes. Sumber:

http://content.time.com/time/world/article/0,8599,2 062604,00.html Diakses 5 April 2016. 